\title{
Atypical glycine encephalopathy
}

INSERM

\section{Source}

INSERM. (1999). Orphanet: an online rare disease and orphan drug data base. Atypical glycine encephalopathy. ORPHA:289863

Atypical glycine encephalopathy is a rare form of glycine encephalopathy (GE; see this term) presenting disease onset or clinical manifestations that differ from neonatal or infantile GE. 